University of South Florida

DIGITAL COMMONS

Digital Commons @ University of

@ UNIVERSITY OF SOUTH FLORIDA

South Florida

School of Geosciences Faculty and Staff

Publications

School of Geosciences

3-1990

\title{
First GPS Baseline Results from the North Andes
}

James N. Knellogg

University of South Carolina

Jeffrey T. Freymuller

University of South Carolina

Timothy H. Dixon

Jet Propulsion Laboratory, thd@usf.edu

Ruth E. Neilan

Jet Propulsion Laboratory

Ropain U. Clemente

Instituto National de Investigaciones Geológico-Mineras

See next page for additional authors

Follow this and additional works at: https://digitalcommons.usf.edu/geo_facpub

Part of the Earth Sciences Commons

\section{Scholar Commons Citation}

Knellogg, James N.; Freymuller, Jeffrey T.; Dixon, Timothy H.; Neilan, Ruth E.; Clemente, Ropain U.; Sergio, M. Camargo; Benjamin, Fernandez Ch.; Stowell, James L.; Salazai, Anibal; Jaime, Mora V.; Espin, Luis; Perdue, Vernon; and Leos, Leonard, "First GPS Baseline Results from the North Andes" (1990). School of Geosciences Faculty and Staff Publications. 512.

https://digitalcommons.usf.edu/geo_facpub/512

This Article is brought to you for free and open access by the School of Geosciences at Digital Commons @ University of South Florida. It has been accepted for inclusion in School of Geosciences Faculty and Staff Publications by an authorized administrator of Digital Commons @ University of South Florida. For more information, please contact digitalcommons@usf.edu. 


\section{Authors}

James N. Knellogg, Jeffrey T. Freymuller, Timothy H. Dixon, Ruth E. Neilan, Ropain U. Clemente, M. Camargo Sergio, Fernandez Ch. Benjamin, James L. Stowell, Anibal Salazai, Mora V. Jaime, Luis Espin, Vernon Perdue, and Leonard Leos 
GEOPHYSICAL RESEARCH LETTERS, VOL. 17, NO, 3, PAGES 211-214, MARCH 1990

\title{
FIRST GPS BASELINE RESULTS FROM THE NORTH ANDES
}

\author{
James N. Kellogg1, Jeffrey T. Freymueller ${ }^{1}$, Timothy H. Dixon ${ }^{2}$, Ruth E. Neilan ${ }^{2}$ \\ Clemente Ropain U. ${ }^{3}$, Sergio Camargo M. ${ }^{4}$, Benjamin Fernandez Ch. ${ }^{4}$, James L. Stowell ${ }^{5}$ \\ Anibal Salazar ${ }^{6}$, Jaime Mora V.6, Luis Espin 7 , Vernon Perdue ${ }^{8}$, Leonard Leos 9
}

\begin{abstract}
The CASA UNO GPS (Global Positioning System) experiment (January-February 1988) has provided the first epoch baseline measurements for the study of plate motions and crustal deformation in and around the North Andes. Two dimensional horizontal baseline repeatabilities are as good as 5 parts in $10^{8}$ for short baselines $(100-1000 \mathrm{~km})$, and better than 3 parts in $10^{8}$ for long baselines $(>1000 \mathrm{~km}$ ). Vertical repeatabilities are typically $4-6 \mathrm{~cm}$, with a weak dependence on baseline length. The expected rate of plate convergence across the Colombia Trench is 6-8 cm/yr, which should be detectable by the repeat experiment planned for 1991. Expected deformation rates within the North Andes are of the order of $1 \mathrm{~cm} / \mathrm{yr}$, which may be detectable with the 1991 experiment.
\end{abstract}

\section{Why Study the North Andean Margin?}

Precise geodetic measurements in the tectonically active North Andean margin (Figure 1, Kellogg and Dixon, this issue) will provide constraints on models for convergent boundary tectonic processes. First, an island located just seaward of the Colombia trench provides the opportunity to directly measure subduction rates for the first time across a short baseline $(399 \mathrm{~km})$. Second, such measurements will help determine whether aseismic convergence is occurring along the Caribbean - North Andean margin. Deformation of the youngest sediments in the South Caribbean deformed belt suggests active aseismic underthrusting of Caribbean crust beneath the deformed belt [e.g., Ladd et al.,1984]. A poorly defined Benioff Zone [Dewey, 1972; Pennington, 1981] has been interpreted as the result of slow subduction of Caribbean crust beneath the North Andes [Kellogg and Bonini, 1982]. Third, repeated precise geodetic measurements in the North Andes will demonstrate whether strain is confined to the plate boundaries or distributed across a broad zone from the South Caribbean marginal fault to the East Andean fold belt [Jordan, 1975].

\footnotetext{
${ }^{1}$ Deparment of Geological Sciences, University of South Carolina, Columbia

2Jet Propulsion Laboratory, Pasadena, California

${ }^{3}$ Instituto Nacional de Investigaciones Geológico-Mineras, Bogotá, Colombia

${ }^{4}$ Division de Geodesia, Instituto Geográfico "Agustin Codazzi", Bogotá, Colombia

${ }^{5}$ UNAVCO CIRES, University of Colorado, Boulder

${ }^{6}$ Instituto Geográfico Militar, Quito, Ecuador

'Observatorio Astronómico, Escuela Politécnica Nacional, Quito, Ecuador Florida

${ }^{8}$ Project Chief, DMA-IAGS Ecuador Project, APO Miami,

${ }^{9}$ Project Chief, DMA-IAGS Colombia Project, APO Miami, Florida
}

Capyright 1990 by the American Ceophysical Union.

Paper number 89GL03675.

$0094-8276 / 90 / 89$ GL-03675\$03.00

\section{Rapid Subduction of the Nazca Plate}

Active subduction of Nazca oceanic lithosphere under the North Andes at the Colombia trench is indicated by a Benioff zone dipping $30^{\circ}$ to the east [Galvis, 1980; Pennington, 1981] and by andesitic volcanism in the Cordillera Central. The rapid subduction is associated with episodic great shallow earthquakes [Pennington, 1981; Kanamori and McNally, 1982]. Between 1899 and 1982 seven large earthquakes $(M \geq 7.5)$ occurred in the North Andes, with an average recurrence inter$\mathrm{val}$ of 13 years [Addicot and Richards, 1984]. All of these were related to subduction of the Nazca plate. Between 1963 and 1981, seventeen earthquakes with $m_{b} \geq 6.0$ were detected in the North Andes, with average recurrence interval of one year [NOAA-EDIS Earthquake Data File]. We can therefore expect that at least one more earthquake of $m_{b} \geq 6.0$ will occur within the network prior to the CASA DOS reoccupation.

One of the most exciting results anticipated after CASA DOS is the direct measurement of the convergence rates across short baselines for rapidly subducting trenches. We can add the South America - North Andean vector $(1.0 \pm 0.2 \mathrm{~cm} / \mathrm{yr}$, $S 55^{\circ} \mathrm{W} \pm 5^{\circ}$ ) [Aggarwal, 1983] and the Nazca - South America vector $\left(7.8 \pm 0.5 \mathrm{~cm} / \mathrm{yr}, \mathrm{N} 80^{\circ} \mathrm{E} \pm 3^{\circ} ; \mathrm{RM} 2\right.$ model of Minster and Jordan [1978] to obtain the Nazca - North Andean vector $\left(6.9 \pm 0.7 \mathrm{~cm} / \mathrm{yr}, \mathrm{N} 83^{\circ} \mathrm{E} \pm 7^{\circ}\right)$ [Kellogg, et al., 1985]. The predicted motion using the NUVEL-1 model [DeMets et al., 1990] is $1 \mathrm{~cm} / \mathrm{yr}$ slower. Colombia trenchcrossing baselines were measured from Malpelo Island to Tumaco $(390 \mathrm{~km})$, Buenaventura $(510 \mathrm{~km})$, Cali $(585 \mathrm{~km})$, Pasto $(570 \mathrm{~km})$, and Quito, Ecuador $(580 \mathrm{~km})$, and from Baltra in the Galapagos Istands to Tumaco (1170 km) (Figure 1 , Kellogg and Dixon, this issue).

\section{Microplate Boundaries and Intraplate Deformation}

There is general agreement that the Caribbean, Nazca, and South America plates are converging, but the directions of relative motion and the locations of the plate boundaries are controversial [e.g., Dewey, 1972; Shagam, 1975; and Aggarwal, 1983]. Kellogg et al. [1985] have interpreted the tectonics in the region by two additional microplates, the Panama and North Andes blocks (Figure 1, Kellogg and Dixon, this issue). The North Andean microplate is bounded by the Colombia Trench and the Panama block on the west and the South Caribbean deformed belt to the north. On the east side of the North Andes, right-lateral movement is taking place on the Bocono-East Andean fault zone (Figure 1, Kellogg and Dixon, this issue). From the short-term seismicity Aggarwal [1983] deduced a seismic-slip rate of $1 \pm 0.2 \mathrm{~cm} / \mathrm{yr}$. Using a measured $100-\mathrm{m}$ right-lateral offset of glacial moraines, Schubert [1980] estimated a similar average rate of strike slip motion on the fault, $0.8 \mathrm{~cm} / \mathrm{yr}$ for the last 12,000 years.

The Panama and North Andes microplates are not rigid, however, and are characterized by considerable internal deformation. The shear stresses distributed throughout the two microplates may be related to the attempted subduction of the Carnegie Ridge and bouyant Caribbean crust and collision with Panama [Wadge and Burke, 1983]. The Romeral fault system is still active, for example. A microearthquake seismometer array rocorded 94 earthquakes during a 17 -month period along the Romeral and Cauca fault zones between $5^{\circ} 50^{\circ}$ 
Table 1. Estimated station locations and RMS repeatabilities from CASA UNO data. All good days of data are used. Coordinate system is an earth-fixed XYZ based on the Goddard Space Flight Center VLBI solution GLB223, with the motion of North America in the AM0-2 model of Minster and Jordan [1978] subtracted.

\begin{tabular}{lrlr}
\hline Station & \multicolumn{1}{c}{ X (cm) } & \multicolumn{1}{c}{$Y(\mathrm{~cm})$} & $Z(\mathrm{~cm})$ \\
\hline Baltra & $-2882306.5 \pm 5.2$ & $-637792712.5 \pm 8.5$ & $-5093880.1 \pm 5.9$ \\
Bogota & $174366228.0 \pm 5.3$ & $-611441797.5 \pm 8.8$ & $53810954.4 \pm 2.5$ \\
Cali & $150189745.2 \pm 9.5$ & $-618761494.8 \pm 17.7$ & $38732874.7 \pm 7.5$ \\
Jerusalen & $128758355.3 \pm 8.6$ & $-624915953.7 \pm 11.3$ & $-65914.6 \pm 1.8$ \\
La Palma & $139282548.1 \pm 7.1$ & $-620917308.6 \pm 25.1$ & $43113619.8 \pm 7.1$ \\
Malpelo & $92884630.6 \pm 7.3$ & $-629463755.8 \pm 15.0$ & $44220580.3 \pm 8.3$ \\
Mocoa & $147747046.1 \pm 8.4$ & $-620410521.0 \pm 27.5$ & $10852709.8 \pm 4.9$ \\
Pasto & $140673027.4 \pm 8.9$ & $-622241406.0 \pm 23.8$ & $13450596.5 \pm 5.5$ \\
Tumaco & $124324540.3 \pm 8.9$ & $-625258487.5 \pm 19.8$ & $20026645.1 \pm 7.6$ \\
Villavicencio & $181982048.6 \pm 5.6$ & $-609671051.2 \pm 9.6$ & $44920197.1 \pm 2.3$ \\
\hline
\end{tabular}

and $7^{\circ} 30 \mathrm{~N}$ [Hutchings et al., 1981]. Composite focal mechanism determinations were compatible with left-lateral movement on near-vertical north-south fault planes from the surface to a depth of $36 \mathrm{~km}$. On March 31, 1983, an earthquake along the fault killed between 250 and 350 people in Popayan, Colombia . First motion data for the earthquake is quite sparse, but the data are consistent with left-lateral displacement on the Romeral fault [Needham, personal communication, 1983]. Present left-lateral movement on the fault system may be intraplate shear attributable to northward escape of the North Andean microplate.

\section{GPS Data Analysis and General Results}

The data was processed at the University of South Carolina and the Jet Propulsion Laboratory (JPL) using the GIPSY software developed at JPL. The method of analysis used for the solutions presented here is described in Freymueller and Kellogg [this issue]. The results shown in this paper are based on a set of single day solutions using the entire CASA UNO extended tracking network. Three stations in North America, with good mutual visibility and proven VLBI-GPS ties, were held fixed to determine the reference frame. No constraints were applied to the positions of the other fiducial stations. Freymueller and Kellogg [this issue] list the stations used in the extended tracking network (Figure 2, Kellogg and Dixon, this issue). The South American stations used in the study are listed in Table 1 . Biases were fixed using the method of Blewitt [1989] with a confidence level of $99.5 \%$ for having fixed all the biases correctly.

Table 1 shows the estimated station positions for the stations considered in this study, along with the RMS repeatabilities for each component. Table 2 lists baseline lengths and RMS repeatabilities derived from the solutions given in Table 1. The baseline length represents only one of three orthogonal components (length, transverse, vertical) of the GPS vector baseline solution. The repeatability in the baseline length is better than $1 \mathrm{~cm}$ for most baselines shorter than $350 \mathrm{~km}$. The largest RMS repeatabilities are for baselines involving Malpelo or La Palma, which had the worst visibility, and Mocoa, which had the worst data outages.

\section{Results for Selected Baselines}

Figures 1-3 show the initial results for the baseline horizontal components for baselines crossing three important tectonic features. Each figure shows the daily solutions for each baseline, with the formal errors shown as error bars. All solutions are plotted about the weighted mean. The baseline horizontal components are computed in the local East-North-
Vertical coordinate system at the first station listed. The agreo ment between the daily RMS repeatability and the formal errors is very good.

All baselines studied here are scheduled to be reoccupied during the CASA DOS experiment in January - February 1991, three years after the initial occupation. An important question remains as to the extent repeatability over several days represents the long-term precision of GPS position determinations [Davis et al., 1989]. Previous results from southem California, where very long baseline interferometry measurements are available for comparison, suggest that GPS accuracy

Table 2. Estimated baseline lengths, RMS repeatabilities, and number of days that each baseline was observed. GPS baselines are determined by differencing the station position estimates. Baseline length is only one of three orthogonal baseline components (length, transverse, vertical). Only one day of common data is available between Pasto and Jerusalen, so no repeatability can be given.

Baseline

Estimated Length (cm) Days

Baltra/Jerusalen
Baltra/Malpelo
Baltra/Tumaco
Bogota/Cali
Bogota/Villavicencio
Cali/Mocoa
Cali/Pasto
Cali/Tumaco
Cali/Villavicencio
La Palma/Cali
La Palma/Tumaco
Malpelo/Bogota
Malpelo/Cali
Malpelo/La Palma
Malpelo/Mocoa
Malpelo/Pasto
Malpelo/Tumaco
Malpelo/Villavicencio
Pasto/Jerusalen
Pasto/Mocoa
Tumaco/Jerusalen
Tumaco/Mocoa
Tumaco/Pasto

$132364487.7 \pm 2.7$ $108039782.5 \pm 3.7$

$130267919.2 \pm 3.0$

$29418167.6 \pm 0.7$

$11839840.9 \pm 0.3$ $28035513.7 \pm 1.1$ $27237317.2 \pm 1.2$ $32575187.0 \pm 0.9$ $33640292.4 \pm 0.9$ $11950110.7 \pm 1.6$ $27849530.3 \pm 0.7$ $84000096.6 \pm 2.0$ $58553643.9 \pm 2.6$ $47191465.9 \pm 1.7$ $64847988.7 \pm 1.2$ $57294727.4 \pm 1.6$ $39893588.9 \pm 2.0$ $91272063.6 \pm 2.4$ $18215611.7 \pm * * *$ $7755187.4 \pm 1.7$ $20578797.4 \pm 0.4$ $25617928.6 \pm 1.8$ $17877935.3 \pm 0.4$ 
may be comparable to GPS precision [Blewitt, 1989; Dong and Bock, 1989]. Assuming that the results for CASA DOS will be comparable in quality to those from CASA UNO, the uncertainty in the baseline change between the experiments is the square root of 2 times the uncertainty of the CASA UNO baseline. A comparison of this uncertainty to the predicted motion can be used to estimate the likelihood that the predicted tectonic motion will be detectable in the difference between solutions from the two experiments.

Except for the baseline from Malpelo to Tumaco $(399 \mathrm{~km}$; Figure 1), all daily solutions for a given baseline have similar

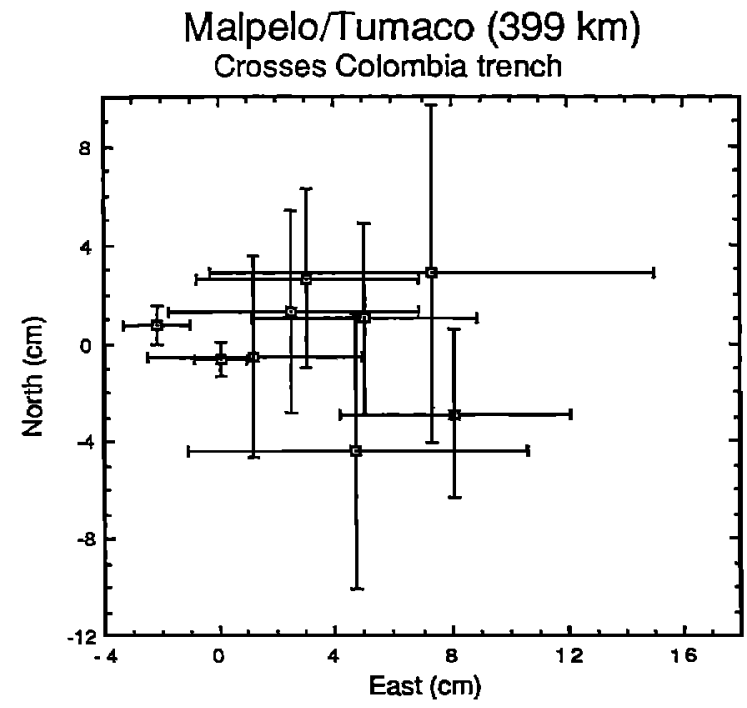

Fig. 1. Daily horizontal baseline solutions for Malpelo to Tumaco $(399 \mathrm{~km}$ ) plotted with respect to their weighted mean. Error bars denote the formal errors (data noise).

formal errors. Two of the daily solutions for the Malpelo to Tumaco baseline have formal errors about one-fourth as large as the other days. On those two days, the observation period was nine hours in length, while the remaining days used a 7.5 hour observation period. This dramatic reduction in formal errors is due to the effect of bias-fixing. On the days with nine hour observation sessions, $62 \%$ of the double-differenced carrier phase biases which included Malpelo as one station were resolved, while only $22 \%$ of these biases were resolved on the days with the short observation session. There was not a significant change in the percentage of biases fixed over the network as a whole.

The baseline from Malpelo to Tumaco (Figure 1) crosses the Colombia Trench. The predicted convergence rate is approximately 6-8 cm/yr directed east-west. The RMS repeatability in the baseline east component is $2.5 \mathrm{~cm}$. The predicted baseline change of $18-24 \mathrm{~cm}$ over 3 years is 5 to 7 times as large as the predicted uncertainty, so it should be detectable if the rate of plate convergence during the three years between experiments is typical of the plate convergence rate averaged over much longer time spans.

The baseline from Bogota to Villavicencio (Figure 2) crosses the East Andean Frontal Fault zone, on which the predicted motion is approximately $1 \mathrm{~cm} / \mathrm{yr}$. Overall RMS horizontal repeatabilities are $4 \mathrm{~mm}$ in the baseline east component and $3 \mathrm{~mm}$ in the baseline north component, for a total two-dimensional uncertainty of $5 \mathrm{~mm}$. The predicted baseline change is approximately three times the predicted uncertainty in the change, so the predicted tectonic motion on this fault is potentially detectable.

The beseline from Bogota to Cali (Figure 3) crosses the Romeral Fault. There is no estimate of the rate of motion along the Romeral Fault. Overall RMS horizontal repeatabilities are 9

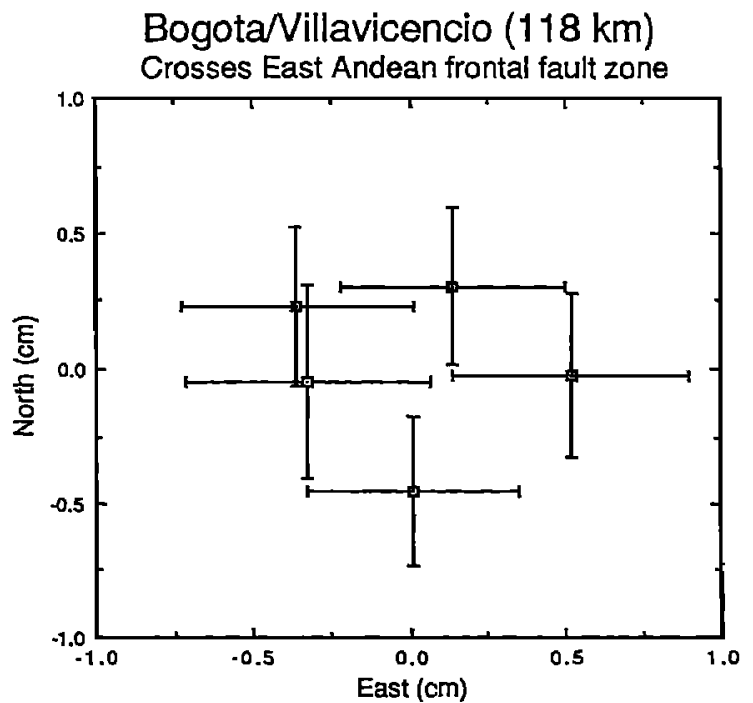

Fig. 2. Daily horizontal baseline solutions for Bogotá to Villavicencio $(118 \mathrm{~km})$ plotted with respect to their weighted mean. Error bars are the same as in Fig. 1.

$\mathrm{mm}$ in the baseline east component and $5 \mathrm{~mm}$ in the baseline north component. An observed displacement of more than 25 $\mathrm{mm}(-9 \mathrm{~mm} / \mathrm{yr})$ in the east component or $14 \mathrm{~mm}(-5 \mathrm{~mm} / \mathrm{yr})$ in the north component would represent motion that is significantly different from zero at the two sigma level (approximately $95 \%$ confidence).

\section{Discussion}

Baseline solutions from the CASA UNO experiment establish a set of first epoch measurements for the monitoring of crustal deformation in the North Andes. Two dimensional horizontal baseline repeatabilites are as good as 5 parts in $10^{8}$ for short baselines, and better than 3 parts in $10^{8}$ for long baselines. Vertical repeatabilities are typically of the order of 4-6 $\mathrm{cm}$, with a weak dependence on baseline length. The quality of solutions from the CASA UNO experiment suggests that convergence across the Colombia Trench will be detectable with the repeat experiment in 1991. The convergence over three years predicted from global plate motion models is several

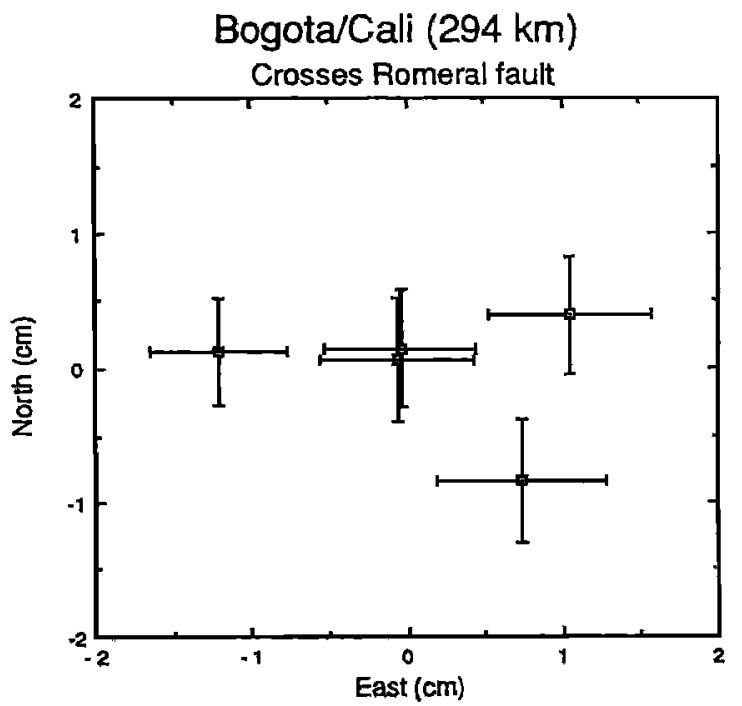

Fig. 3. Daily horizontal baseline solutions for Bogoté to Cali $(294 \mathrm{~km})$. Error bars are the same as in Fig. 1. 
times the level of repeatability for baselines crossing the trench. On shorter baselines on the continent, intraplate deformation or block motion may be detectable as well. The predicted motion over three years is several times larger than the repeatability of a baseline crossing the East Andean Frontal Fault system.

The importance of the length of data arc on the baseline solutions for Malpelo to Tumaco was greater than that predicted by previous studies [e.g., Golombek et al., 1987; Freymueller and Golombek, 1988]. Due to the isolated location of Malpelo, almost $400 \mathrm{~km}$ away from the nearest other station in the network, and possibly due also to the poor satellite constellation and visibility at Malpelo, the longer data arc made bias-fixing possible.

Acknowledgements. The authors wish to again thank all the GPS field observers acknowledged by Kellogg et al. [1989], and R. Alvarado R. and R. Steer, Secretary Generals of Comision Colombiana de Oceanografia who arranged for transportation $500 \mathrm{~km}$ to and from Malpelo Island on Colombian naval vessels. The TI-4100 GPS receivers were supplied by the University NAVSTAR Consortium, Boulder, Colo., U.S. Defense Mapping Agency, and U.S. Naval Oceanographic Office, Bay St. Louis. A D-series WVR was supplied by JPL. Two anonymous reviewers improved the manuscript. Support for U.S. participants was from NSF grant EAR-8617485, NASA, the University of South Carolina, and the University NAVSTAR Consortium.

\section{References}

Addicot, W.O., and P.W. Richards, Plate tectonic map of the circum-Pacific region, Pacific basin sheet, $A A P G$, Tulsa, Oklahoma, 1984.

Aggarwal, Y., Seismic slip rates and earthquakes rupture zones in the southern Caribbean: implications for plate motions and earthquake hazard in this region (abstract) Abstracts of the Caribbean Geological Conference, 10th $16,1983$.

Blewitt, G., Carrier Phase Ambiguity Resolution for the Global Positioning System Applied to Geodetic Baselines up to $2000 \mathrm{~km}, J$. Geophys. Res., 94, 10,187-10,203, 1989.

Davis, J. L., W. H. Prescott, J. L. Svarc, and K. J. Wendt, Assessment of Global Positioning System measurements for studies of crustal deformation, J. Geophys. Res., 94, $13,635-13,650,1989$.

DeMets, C., R. G. Gordon, D. F. Argus, and S. Stein, Current plate motions, Geophysical Journal of the RAS, $D G G$ and $E G S$, in press, 1990.

Dewey, J.W., Seismicity and tectonics of Western Venezuela, Bulletin of Seismological Society of America, 62, 1711$1751,1972$.

Dong, D., and Y. Bock, Global Positioning System network analysis with phase ambiguity resolution applied to crustal deformation studies in California, J. Geophys. Res., 24, 3949-3966, 1989.

Freymueller, J.T., and M.P. Golombek, Geometry and treak ment of fiducial networks: effect on GPS baseline precision in South America, Geophys. Res. Letters, 15, 1467 $1469,1988$.

Freymueller, J., and J. Kellogg, The Extended Tracking Network and Indications of Baseline Precision and Accuracy in the North Andes, Geophys. Res. Let., this issue, 1990.

Galvis Vergara, J., Un arco de islas Terciario en el Occidente Colombiano, Geologia Colombiana, 11, 1980.

Golombek, M.P., J.T. Freymueller, L.L. Skrumeda, S.A. Stephens, D.M. Tralli, J. Davidson, and T.H. Dixon, Dependence of GPS baseline accuracy in Central and South America on fiducial network geometry, paper pro- sented at the 19th IUGG General Assembly, Vancouver, v. 1, p. $20,1987$.

Hutchings, L., T. Turcotte, J. McBride, and H. Ochoa, Microseismicity along and near the Dolores shear zone in Antioquia, Colombia, Woodward-Clyde Consultants for Interconexion Electrica S.A., 1981.

Jordan, T., The present-day motions of the Caribbean plate, J. Geophys. Res., 80, 4433-4439, 1975.

Kanamori, H., and K.C. McNally, Variable rupture mode of the subduction zone along the Ecuador-Colombia coast, Bull. Seis. Soc. Amer, 72, 1241-1253, 1982.

Kellogg, J.N., and W.E. Bonini, Subduction of the Caribbean plate and basement uplifts in the overriding South American plate, Tectonics, 1, 251-276, 1982.

Kellogg, J. N. and T. H. Dixon, Central and South America GPS Geodesy - CASA UNO, Geophys. Res. Let., this issue, 1990.

Kellogg, J.N., I.J. Ogujiofor, and D.R. Kansakar, Cenozoic tectonics of the Panama and North Andes blocks, Memorias, Sixth Latin American Geological Congress, Bogota, Colombia , 1, 40-59, 1985.

Kellogg, J., T. Dixon, and R. Neilan, CASA, Central and South America GPS Geodesy, EOS Trans. Am. Geophys. Union, 70, no. 24, pp. 649, 651, 655-656, 1989.

Ladd, J.W., M. Truchan, M. Talwani, P.L. Stoffa, P. Buhl, R. Houtz, A. Mauffret, and G. Westbrook, Seismic reflection profiles across the southem margin of the Caribbean, in Caribbean-South American Plate Boundary and Regional Tectonics, edited by W.E. Bonini, R.B. Hargraves, and R. Shagam, Memoirs of the Geological Society of America, 162, pp. 153-159, 1984.

Minster, J.B., and T.H. Jordan, Present day plate motions, J. Geophys. Res., 83, 5331-5354, 1978.

Pennington, W.D., Subduction of the eastern Panama basin and the seismotectonics of northwestern South America, J. Geophys. Res., 86, 10,753-10,770, 1981.

Schubert, C., Late-Cenozoic pull-apart basins, Bocono fault zone, Venezuelan Andes, Journal of Structural Geology 2 463-468, 1980.

Shagam, R., The northern termination of the Andes, in The Ocean Basins and Margins, 3, edited by A.E.M. Nairn and E.G. Stehli, pp. 325-420, Plenum, New York, 1975.

Wadge, G., and K. Burke, Neogene Caribbean plate rotation and associated Central American tectonic evolution Tectonics, 2 , 633-643, 1983.

S. Camargo and B. Fernandez, Division de Geodesia, Instituto Geográfico "Agustin Codazzi", Carrera 30, No. 4851, Bogotá, Colombia.

T. Dixon and R. Neilan, JPL, MS 183-701, 4800 Oak Grove Dr., Pasadena, CA 91109.

L. Espin, Observatorio Astronómico, Apartado 165, Escuela Politécnica Nacional, Quito, Ecuador.

J. Freymueller and J. Kellogg, Dept. of Geological

Sciences, Univ. of South Carolina, Columbia, SC 29208.

L. Leos, Project Chief, DMA-IAGS Colombia Project, APO Miami, FL 34038.

J. Mora and A. Salazar, Instituto Geográfico Militar, Quito, Ecuador.

V. Perdue, Project Chief, DMA-IAGS Ecuador Project, APO Miami, FL 34039.

C. Ropain, Instituto Nacional de Investigaciones Geológico-Mineras, INGEOMINAS, Diagonal 53, No. 34653, Apartado Aereo 4865, Bogotá, Colombia.

J. Stowell, UNAVCO CIRES / Campus Box 216, Univ. of Colorado, Boulder, Colorado 80309.

(Received: November 9, 1989 ;

Accepted: December 11, 1989) 